\title{
Antiproliferative activity of new benzimidazole derivatives
}

\author{
Katarzyna Błaszczak-Świątkiewicz ${ }^{凶}$, Paulina Olszewska and Elżbieta Mikiciuk-Olasik \\ Department of Pharmaceutical Chemistry and Drug Analysis, Medical University, Lodz, Poland
}

\begin{abstract}
A series of new benzimidazole derivatives were synthesized and tested in vitro for possible anticancer activity. Their effect of proliferation into selected tumor cell lines at normoxia and hypoxia conditions was determined by WST-1 test. Additionally, apoptosis test (caspase 3/7 assay) was used to check the mode caused by the agents of cell death. Four of the examined compounds $(7,8$, $13,11)$ showed a very good antiproliferative effect and three of them were specific for hypoxia conditions $(8,14$, 11). Compound 8 was the most cytotoxic against human lung adenocarcinoma A549 cells at hypoxic conditions. Hypoxia/ normoxia cytotoxic coefficient of compound 14 (4.75) is close to hypoxia/normoxia cytotoxic coefficient of tirapazamine (5.59) - a reference compound in our experiments and this parameter locates it between mitomycin C and 2-nitroimidazole (misonidazole). Screening test of caspase-dependent apoptosis proved that exposure to A549 cells of compounds 7-8 and 13-14 for $48 \mathrm{~h}$ promote apoptotic cell death. These results supplement our earlier study of the activity of new potentialy cytotoxic heterocyclic compounds against selected tumor cells.
\end{abstract}

Key words: anticancer activity, ntiproliferation, apoptosis, benzmidazole, hypoxia, nitrobenzimidazole

Received: 18 February, 2013; revised: 23 May, 2013; accepted: 05 June, 2013; available on-line: 25 July, 2013

\section{INTRODUCTION}

Hypoxia which is typical for solid tumours is a specific condition which induces adaptive processes such as angiogenesis, erythropoiesis and alteration of the metabolism of tumour cells (Forsythe et al., 1996; Vaupel, 2004). Hypoxia-inducible factor (HIF-1) plays an important role in the reprogramming of cancer metabolism by activating transcription of genes encoding glucose transporters and glycolytic enzymes leading to increased glucose uptake and pyruvate dehydrogenase kinase 1 (PDK1), which diminishes mitochondrial respiration. The change from oxidative to glycolytic metabolism allows maintenance of redox homeostasis, survival and continued proliferation of cancer cells under hypoxic conditions (Kim et al., 2006; Singh, et al., 2011).

In order to minimize those survival effects of tumor cells, scientists conduct research into targeted therapy with the use of specific substances which have a bioreductive mechanism of action at hypoxia conditions (Albertella et al., 2008; Błaszczak-Swiątkiewicz et al., 2012; Meng et al., 2003). They look for new medicines such as analogues of nitro compounds (CB 1954) and heterocyclic N-oxides (tirapazamine, AQ4N) (Fig. 1c-e) (Kurtzberg et al., 2011; Łazowski, 2007; Semenza, 1999). The antiproliferative action of medicines is at present one of the most important factors in combating neoplastic diseases. Benzimidazole derivatives are known inhibitors of cell proliferation an (Alpan et al., 2007; 2009; Alper et al., 2003) are intensively being studied as they might have anticancer properties (Coban et al., 2009; OmyłaStaszewska et al., 2003; Panieres et al., 2000; Vaupel, 2004; Wu et al., 2010). This was the reason for initiating our experiments on a group of new benzimidazole derivatives and $\mathrm{N}$-oxide benzimidazole derivatives. We synthesized a series of benzimidazole derivatives (7-18) to elucidate their antiproliferative activity at normoxia and hypoxia conditions (Scheme 1). Particularly selective activity of $\mathrm{N}$-oxide benzimidazole derivatives into hypoxia was very interesting. Additionally we wanted to determine if the cytotoxic activity led to the cells death by necrosis or apoptosis.

\section{EXPERIMENTAL}

Materials and Methods. Chemistry. IR spectra ( $\mathrm{KBr}$ discs) were registered using a Mattson Infinity Series FTIR spectrophotometer (USA). ${ }^{1} \mathrm{H}$ and ${ }^{13} \mathrm{C}$ spectra were recorded on a $300 \mathrm{MHz}$ Varian Mercury spectrometer (Germany) in DMSO or $\mathrm{CDCI}_{3}$ as solvent and tetramethylsilane (TMS) as internal reference. MS spectra (FAB method, M+1, matrix - glycerine) were recorded on a Finnigan Mat 95 spectrometer (Brema, Germany). Carbon, hydrogen and nitrogen elemental analyses were performed using a Perkin Elmer 2400 series II CHNS/O analyzer (Madison, USA) and agreed with proposed structures within $\pm 0.3 \%$ of theoretical values.

Chromatographic purification was performed on HPTLC and silica gel plates (Merck $F_{254}$, Darmstadt, Germany) with indicated eluents. Chemicals and solvents were obtained from commercial sources.

Selected compounds were purified on a Waters 600 LC HPLC system with a Supelco RP-18 column $(15 \mathrm{~cm}$ $\times 4 \mathrm{~mm} \times 5 \mu \mathrm{m}$ plus symmetry C18 guard, Waters) held at $20^{\circ} \mathrm{C}$. Chromatographic peaks were identified with a UV detector (Waters) (Błaszczak-Świątkiewicz et al., 2012).

General procedure for preparation of compounds 7-12 by directed cyclocondensation. A mixture of equimolar portions of 4-nitro-1,2-phenylenediamine (10 mmol) (2) or 4-chloro-1,2-phenylenediamine (1) and the appropriate aldehyde (3-6) $(10 \mathrm{mmol})$ were dissolved in $50 \mathrm{ml}$ anhydrous ethanol and heated for $24 \mathrm{~h}$ under reflux. Then $24 \mathrm{~h}$ nitrobenzene $(3 \mathrm{ml})$ was added and the mixture was heated for another $24 \mathrm{~h}$. Next, the reaction

$\triangle$ e-mail: katarzyna.blaszczak-swiatkiewicz@umed.lodz.pl Abbreviations: T, tirapazamine, WST-1, water-soluble tetrazolium salt; DMSO, dimethyl sulfoxide; $\mathrm{CDCl}_{3}$, deuterated chloroform; FBS, fetal bovine serum; CTR, control sample. 
mixture was concentrated to half its initial volume and a crude precipitate was filtered off. As a result, in this reaction the following compounds (7-18) were obtained with chromatographic pure. Chemically homogeneous obtained compounds were confirmed using 25 TLC aluminium sheets with silica gel $60 \mathrm{~F}_{254}$ and a mixture: chloroform/methanol $6.25 \% \mathrm{v} / \mathrm{v}$ as eluent.

General procedure for preparation of compounds 13-18. Anhydrous acetic acid $15 \mathrm{ml}$ and $10 \mathrm{mmol}$ hydrogen peroxide were added to $10 \mathrm{mmol}$ of appropriate derivatives of benzimidazole. The mixture was heated under reflux at $50-60^{\circ} \mathrm{C}$. After six hours another $5 \mathrm{mmol}$ of hydrogen peroxide was added. After $24 \mathrm{~h}$ heating, the mixture was concentrated in vacuo to a small volume, diluted with methylene chloride, and washed with sodium carbonate solution. The organic layer was dried, concentrated in vacuo and diluted with diethyl ether. The solid precipitate was filtered off and recrystallized from isopropanol. Chromatogaphic purity of the obtained compounds was confirmed by TLC as above.

\section{2-(4-Chlorophenyl)-5-nitro-1H-benzoimidazole (7)}

Yield 70\%, IR (KBr) v/ $\mathrm{cm}^{-1}: 3289$ (NH), 1536 (NO $\mathrm{N}_{2}$ asym), $1332 \quad\left(\mathrm{NO}_{2}\right.$ sym $) 1499(\mathrm{C}=\mathrm{N}) ; \mathrm{H}^{1} \quad \mathrm{NMR}$ $\left(\mathrm{DMSO}_{\mathrm{f}}\right) \delta: 14(\mathrm{~s}, 1 \mathrm{H}, \mathrm{NH}), 7.6(\mathrm{dd}, 2 \mathrm{H}, \mathrm{CH}, \mathrm{J}=2.6 \mathrm{~Hz})$, 7.8 (dd,2H,CH, J=0.4 Hz), 8.1 (dd,2H,CH, J=2.2 Hz), $8.4(\mathrm{~s}, 1 \mathrm{H}, \mathrm{CH}) ;{ }^{13} \mathrm{C}$ NMR $\left(\mathrm{DMSO}_{6} \mathrm{~d}_{6}\right)$ 8: 143.4, 142.8, $136.7,135.7,135.4,129.8,129.3,128.7,127.9,125.5$, 123.3; MS m/ : 274.2, 272.2; calculated for $\mathrm{C}_{13} \mathrm{H}_{8} \mathrm{Cl}$ $\mathrm{N}_{3} \mathrm{O}_{2}$ : C 57.05, H 2.95, N 15.35; found C 56.83, H 2.94, $\mathrm{N} 15.29 . \mathrm{R}_{\mathrm{f}}=0.52$.

\section{5-Nitro-2-(2-nitrophenyl)-1H-benzoimidazole (8)}

Yield 55\%, IR (KBr) v/ $\mathrm{cm}^{-1}: 3418$ (NH), 1516 (NO asym), 1342 ( $\mathrm{NO}_{2}$ sym) $1472(\mathrm{C}=\mathrm{N}) ; \mathrm{H}^{1} \quad \mathrm{NMR}$ $\left(\mathrm{DMSO}_{6}\right) \quad \delta: 14(\mathrm{~s}, 1 \mathrm{H}, \mathrm{NH}), 7.8$ (dd, 2H,CH, J=1.6 $\mathrm{Hz}), 8.0$ (dd,2H,CH, J=1.4 Hz), 8.1 (dd,2H,CH, J=0.8 $\mathrm{Hz}), 8.6(\mathrm{~s}, 1 \mathrm{H}, \mathrm{CH}) ;{ }^{13} \mathrm{C}$ NMR (DMSO-d $)$ ) 8 : 148.8, $142.9,133.9,133.1,131.9,129.6,128.0,126.4,124.6$, 119.6, 116.5, 113.0: MS m/ : 285.2, 283.3; calculated for $\mathrm{C}_{13} \mathrm{H}_{8} \mathrm{~N}_{4} \mathrm{O}_{4}$ : C 54.93, H 2.83, N 19.71; found C 54.78, H 2.84, N 19.67. $R_{\mathrm{f}}=0.50$.

\section{2-Benzo[1,3]dioxol-5-yl-5-nitro-1H-benzoimidazole (9)}

Yield 65\%, IR (KBr) v/ $\mathrm{cm}^{-1}$ : $3331(\mathrm{NH}), 2914\left(\mathrm{CH}_{2}\right)$, 1505 ( $\mathrm{NO}_{2}$ asym), 1300 ( $\left.\mathrm{NO}_{2} \mathrm{sym}\right) 1482(\mathrm{C}=\mathrm{N}), 1257$ (C-O-Csym), 1036 (C-O-Casym); $\mathrm{H}^{1}$ NMR (DMSO-d

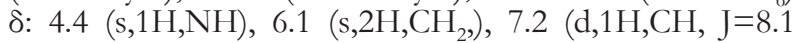
$\mathrm{Hz}), 7.6(\mathrm{~s}, 2 \mathrm{H}, \mathrm{CH}), 7.8(\mathrm{~d}, 1 \mathrm{H}, \mathrm{CH}, \mathrm{J}=1.8 \mathrm{~Hz}), 8.1$ (d, $1 \mathrm{H}, \mathrm{CH}, \mathrm{J}=2.2 \mathrm{~Hz}$ ), 8.4 (s, 1H, CH); ${ }^{13} \mathrm{C}$ NMR (DMSO-d $\left.{ }_{6}\right)$ o: 149.7, 147.9, 143.6, 142.5, 136.7, 135.3, 133.2, $129.8,123.3,122.8,121.9,117.8,116.0,101.9$; MS $m /$; 284.2, 282.1; calculated for $\mathrm{C}_{14} \mathrm{H}_{9} \mathrm{~N}_{3} \mathrm{O}_{4}$ : C 59.37, H 3.20, $\mathrm{N} 14.84$; found C 59.15, H 3.21, N 14.90. $R_{\mathrm{f}}=0.48$.

\section{2-Naphthyl-5-nitro-1H-benzoimidazole (10)}

Yield 60\%, IR (KBr) v/ $\mathrm{cm}^{-1}: 3422(\mathrm{NH}), 3043(\mathrm{ArH})$, 1523 ( $\mathrm{NO}_{2}$ asym), 1343 ( $\mathrm{NO}_{2}$ sym $), 1474(\mathrm{C}=\mathrm{N}) ; \mathrm{H}^{1}$ NMR (DMSO-d $\left.)_{6}\right) \delta: 6.0(\mathrm{~s}, 1 \mathrm{H}, \mathrm{NH}), 7.6(\mathrm{~d}, 1 \mathrm{H}, \mathrm{CH}, \mathrm{J}=1.6$ $\mathrm{Hz})$ $\delta: 7.8(\mathrm{~d}, 1 \mathrm{H}, \mathrm{CH}, \mathrm{J}=8.9 \mathrm{~Hz}), 8.0(\mathrm{dd}, 2 \mathrm{H}, \mathrm{CH}, \mathrm{J}=8.3$ $\mathrm{Hz}), 8.1$ (s,1H,CH), 8.2 (dd, 2H,CH, J=2.2 Hz) 8.4 (s, $1 \mathrm{H}, \mathrm{CH}), 8.5(\mathrm{~s}, 1 \mathrm{H}, \mathrm{CH}), 8.8(\mathrm{~s}, 1 \mathrm{H}, \mathrm{CH}) ;{ }^{13} \mathrm{C} \mathrm{NMR}$

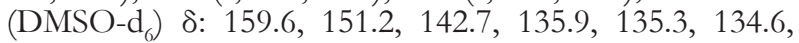
$133.9,133.8,132.6,131.8,129.8,128.8,128.7,128.2$, 127.7, 124.4, 112.9; MS m/ ₹: 290.1, 288.2; calculated for $\mathrm{C}_{17} \mathrm{H}_{11} \mathrm{~N}_{3} \mathrm{O}_{2}$ : C 70.58, H 3.83, N 14.53; found C 70.30, H 3.82, N 14.49. $R_{f}=0.49$.

\section{2-Benzo[1,3]dioxol-5-yl-5-chloro-1H-benzoimidazole (11)}

Yield 65\%, IR (KBr) v/ $\mathrm{cm}^{-1}: 3356(\mathrm{NH}), 2963\left(\mathrm{CH}_{2}\right)$, 1469 (C=N), 1261 (C-O-Csym), 1095 (C-O-Casym); ${ }^{1}$ NMR (DMSO-d $)$ $)$ : $4.5(\mathrm{~s}, 1 \mathrm{H}, \mathrm{NH}) 6.2\left(\mathrm{~s}, 2 \mathrm{H}, \mathrm{CH}_{2}\right)$, $7.3(\mathrm{~d}, 1 \mathrm{H}, \mathrm{CH}, \mathrm{J}=8.3 \mathrm{~Hz}), 7.5$ (d, $1 \mathrm{H}, \mathrm{CH}, \mathrm{J}=2.0 \mathrm{~Hz}$ ), $7.7(\mathrm{dd}, 2 \mathrm{H}, \mathrm{CH}, \mathrm{J}=8.7 \mathrm{~Hz}), 7.9$ (dd, 2H,CH, J=1.8 $\mathrm{Hz}) ;{ }^{13} \mathrm{C}$ NMR (DMSO-d $)$ o: 152.9, 149.3, 148.8, 132.8, $130.9,129.2,124.1,123.9,122.6,116.6,115.8,112.3$, 111.0; MS m/ ; 273.1, 271.1; calculated for $\mathrm{C}_{14} \mathrm{H}_{9} \mathrm{Cl}$ $\mathrm{N}_{2} \mathrm{O}_{2}$ : C 61.66, H 3.33, N 10.27; found: C 61.43, H 3.34, $\mathrm{N} 10.24 . R_{\mathrm{f}}=0.52$.

\section{5-Chloro-2-naphthyl-1H-benzoimidazole (12)}

Yield 60\%, IR (KBr) v/ $\mathrm{cm}^{-1}$ : $3311(\mathrm{NH}), 3043(\mathrm{ArH})$, $1474(\mathrm{C}=\mathrm{N}) ; \mathrm{H}^{1} \mathrm{NMR}\left(\mathrm{DMSO}-\mathrm{d}_{6}\right)$ 8: $4.5(\mathrm{~s}, 1 \mathrm{H}, \mathrm{NH}), 8.9$ $(\mathrm{s}, 1 \mathrm{H}, \mathrm{CH}), 8.3(\mathrm{~d}, 1 \mathrm{H}, \mathrm{CH}, \mathrm{J}=1.6 \mathrm{~Hz}), 8.2$ (d, 1H, CH, $\mathrm{J}=8.7 \mathrm{~Hz}), 8.1(\mathrm{dd}, 2 \mathrm{H}, \mathrm{CH}, \mathrm{J}=6.1 \mathrm{~Hz}), 7.8(\mathrm{dd}, 2 \mathrm{H}$, $\mathrm{CH}, \mathrm{J}=8.7 \mathrm{~Hz}), 7.6(\mathrm{dd}, 2 \mathrm{H}, \mathrm{CH}, \mathrm{J}=5.0 \mathrm{~Hz}), 7.5(\mathrm{~d}, 1 \mathrm{H}$, $\mathrm{CH}, \mathrm{J}=2.0 \mathrm{~Hz}) ;{ }^{13} \mathrm{C}$ NMR (DMSO-d 6$) \delta: 152.5,137.9$, $133.7,132.7,128.7,128.5,128.2,127.5,127.1,126.8$, $126.5,126.4,125.5,123.8,122.8,117.8,116.0$; MS m/ : 279.1, 277.1; calculated for $\mathrm{C}_{17} \mathrm{H}_{11} \mathrm{ClN}_{2}$ : C 73.25, H 3.98, $\mathrm{N} 10.50$; found C 72.98, H 3.99, N 10.47. $R_{\mathrm{f}}=0.53$.

\section{2-(4-Chlorophenyl)-5-nitro-1H-benzoimidazole N-oxide (13)}

Yield 55\%, IR (KBr) v/ $\mathrm{cm}^{-1}: 3287$ (NH), 1536 (NO asym), 1331 ( $\mathrm{NO}_{2}$ sym), $1498(\mathrm{C}=\mathrm{N}), 1290$ (N-O); $\mathrm{H}^{1}$ NMR (DMSO-d $)_{6}$ ) $\delta: 13.7$ (s,1H,NH), 8.5 (s, 1H,CH), $8.3(\mathrm{~d}, 1 \mathrm{H}, \mathrm{CH} \mathrm{J}=2.6 \mathrm{~Hz}), 8.2$ (dd,2H,CH, J=4.9 Hz), 7.7 $(\mathrm{dd}, 2 \mathrm{H}, \mathrm{CH}, \mathrm{J}=2.4 \mathrm{~Hz}), 7.6$ (d, $1 \mathrm{H}, \mathrm{CH}, \mathrm{J}=4.9 \mathrm{~Hz}) ;{ }^{13} \mathrm{C}$ NMR (DMSO-d $)$ o: 151.8, 150.1, 147.8, 144.3, 139.8, $135.3,133.9,129.6,126.2,124.4,118.6,116.1,112.9$; MS m/ : 288.1; calculated for $\mathrm{C}_{13} \mathrm{H}_{8} \mathrm{ClN}_{3} \mathrm{O}_{3} \mathrm{C}$ 53.90, $\mathrm{H}$ 2.78, $\mathrm{N} 14.51$; found $\mathrm{C} 53.71, \mathrm{H} 2.77, \mathrm{~N} 14.57$. $R_{\mathrm{f}}=0.51$.

\section{5-Nitro-2-(2-nitrophenyl)-1H-benzoimidazole $\mathrm{N}$-oxide (14)}

Yield 45\%, IR (KBr) v/ cm ${ }^{-1}: 3380(\mathrm{NH})$ 2963 $\left(\mathrm{CH}_{2}\right)$, $1467(\mathrm{C}=\mathrm{N}), 1518\left(\mathrm{NO}_{2}\right.$ asym) $1342\left(\mathrm{NO}_{2}\right.$ sym), 1261 (N-O); $\mathrm{H}^{1}$ NMR (DMSO-d $)$ $\delta: 13.8$ (s,1H,NH), 8.5 (s, $1 \mathrm{H}, \mathrm{CH}), 8.1(\mathrm{~d}, 1 \mathrm{H}, \mathrm{CH} \mathrm{J}=1.4 \mathrm{~Hz}), 8.0(\mathrm{~d}, 1 \mathrm{H}, \mathrm{CH}, \mathrm{J}=7.5$ $\mathrm{Hz}), 7.90(\mathrm{dd}, 2 \mathrm{H}, \mathrm{CH}, \mathrm{J}=1.2 \mathrm{~Hz}), 7.83(\mathrm{~s}, 1 \mathrm{H}, \mathrm{CH}), 7.81$ (d, $1 \mathrm{H}, \mathrm{CH}, \mathrm{J}=1.4 \mathrm{~Hz}$ ); ${ }^{13} \mathrm{C}$ NMR (DMSO-d 6 ) 151.8, 150.1, $147.8,144.3,139.8,135.3,133.9,129.6,126.2,124.4$, 118.6, 116.1, 112.9; MS m/ ₹: 301.0, 299.0; calculated for $\mathrm{C}_{13} \mathrm{H}_{8} \mathrm{~N}_{4} \mathrm{O}_{5}$ : C 52.01, H 2.69, N 18.66; found C 52.14, $\mathrm{H} 2.70, \mathrm{~N} 18.60 . \mathrm{R}_{\mathrm{f}}=0.50$.

\section{2-Benzo[1,3]dioxol-5-yl-5-nitro-1H-benzimidazole N-oxide (15)}

Yield 75\%, IR ( $\mathrm{KBr}) \mathrm{v} / \mathrm{cm}^{-1}: 3330(\mathrm{NH}), 1482(\mathrm{C}=\mathrm{N})$, 1504 ( $\mathrm{NO}_{2}$ asym), 1300 ( $\mathrm{NO}_{2}$ sym), 1237 (C-O-Casym), 1258 (N-O), 1037 (C-O-Csym); $\mathrm{H}^{1}$ NMR (DMSO-d ${ }_{6}$ ) $\delta: 13.5$ (s,1H,NH), 8.4 (s,1H,CH, 8.2-8.1 (dd,2H,CH, $\mathrm{J}=8.5,8.9 \mathrm{~Hz}), 7.8-7.7$ (dd,2H,CH, J=7.7, 8.3 Hz), 7.1 $(\mathrm{d}, 1 \mathrm{H}, \mathrm{CH}, \mathrm{J}=0.4 \mathrm{~Hz}), 6.1\left(\mathrm{~s}, 2 \mathrm{H}, \mathrm{CH}_{2}\right)$; ${ }^{13} \mathrm{C} \mathrm{NMR}$ (DMSO-d ${ }_{6}$ ) : 155.6, 149.6, 147.9, 142.4, 135.3, 129.8, 123.3, 123.3, 122.9, 121.8, 117.8, 108.8, 106.7, 101.9; MS m/ : 300.2 , 298.1; calculated for $\mathrm{C}_{14} \mathrm{H}_{9} \mathrm{~N}_{3} \mathrm{O}_{5}$ : C 56.19, H 3.03, $\mathrm{N}$ 14.04; found C 56.40, H 3.03, N 13,99. $R_{f}=0.51$.

\section{2-Naphthyl-5-nitro-1H-benzimidazole $\mathrm{N}$-oxide (16)}

Yield 60\%, IR (KBr) v/ $\mathrm{cm}^{-1}$ : $3380(\mathrm{NH}), 3100(\mathrm{ArH})$, 1523 ( $\mathrm{NO}_{2}$ asym), $1474(\mathrm{C}=\mathrm{N}), 1344\left(\mathrm{NO}_{2}\right.$ sym $), 1261$ (N-O); $\mathrm{H}^{1}$ NMR (DMSO-d ${ }_{6}$ ) $\delta: 13.8$ (s.1H,NH), 8.8 (s, $1 \mathrm{H}, \mathrm{CH}), 8.5$ (s,1H,CH), 8.3 (dd, 2H,CH, J=1.4, $1.6 \mathrm{~Hz})$, 
$8.2(\mathrm{~d}, 1 \mathrm{H}, \mathrm{CH}, \mathrm{J}=2.2 \mathrm{~Hz}), 8.1$ (d, 1H,CH, J=2.8 Hz), 8.0 (d, $1 \mathrm{H}, \mathrm{CH}, \mathrm{J}=3.4 \mathrm{~Hz}), 7.8(\mathrm{~d}, 1 \mathrm{H}, \mathrm{CH}, \mathrm{J}=8.7 \mathrm{~Hz}$ ), 7.6 (dd, $2 \mathrm{H}, \mathrm{CH}, \mathrm{J}=2.9 \mathrm{~Hz}) ;{ }^{13} \mathrm{C}$ NMR $\left(\mathrm{DMSO}_{-} \mathrm{d}_{6}\right)$ 8: 172.1 , $155.8,142.8,133.9,132.7,128.9,128.7,127.9,127.8$, 127.2, 126.9, 126.4, 123.9, 118.2; MS m/ : 306.1, 304.1; calculated for $\mathrm{C}_{17} \mathrm{H}_{11} \mathrm{~N}_{3} \mathrm{O}_{3}: \mathrm{C}$ 66.88, $\mathrm{H}$ 3.63, $\mathrm{N}$ 13.76; found $\mathrm{C}$ 66.65, H 3.64, N 13.72. $R_{f}=0.53$.

\section{2-Benzo[1,3]dioxol-5-yl-5-chloro-1H-benzimidazole N-oxide (17)}

Yeld 65\%, IR (KBr) v/ cm ${ }^{-1}: 3303(\mathrm{NH}), 2908\left(\mathrm{CH}_{2}\right)$, $1468(\mathrm{C}=\mathrm{N}), 1257$ (C-O-Casym), 1358 (N-O), 1095 (C-O-Csym); $\mathrm{H}^{1}$ NMR (DMSO-d $\left.{ }_{6}\right)$ : 4.0 (s,1H,NH), $6.2\left(\mathrm{~s}, 2 \mathrm{H}, \mathrm{CH}_{2}\right), 7.2(\mathrm{~d}, 1 \mathrm{H}, \mathrm{CH} \mathrm{J}=8.1 \mathrm{~Hz}), 7.4(\mathrm{~d}, 1 \mathrm{H}, \mathrm{CH}$ $\mathrm{J}=7.7 \mathrm{~Hz}), 7.7$ (d,1H,CH J=9.5 Hz), 7.75 (s, 1H, CH), $7.8(\mathrm{~s}, 1 \mathrm{H}, \mathrm{CH}), 7.85(\mathrm{~d}, 1 \mathrm{H}, \mathrm{CH} \mathrm{J}=8.3 \mathrm{~Hz}) ;{ }^{13} \mathrm{C} \mathrm{NMR}$ $\left(\mathrm{DMSO}_{6}\right)$ $\delta: 165.0,150.8,150.2,148.0,128.6,123.2$, $118.2,116.1,115.2,114.9,113.5,109.1,107.1,102.4$; MS $\mathrm{m} /$;: 289.1287 .1 ; calculated for $\mathrm{C}_{14} \mathrm{H}_{9} \mathrm{ClN}_{2} \mathrm{O}_{3}: \mathrm{C} 58.25, \mathrm{H}$ 3.14, N 9.70; found C 58.03 H 3.13, N 9.68. $R_{f}=0.50$.

\section{5-Chloro-2-naphthyl-1H-benzimidazole N-oxide (18)}

Yield 75\%, IR (KBr) v/ $\mathrm{cm}^{-1}: 3385(\mathrm{NH}), 3059$ (ArH), $1449(\mathrm{C}=\mathrm{N}), 1230(\mathrm{~N}-\mathrm{O}) ; \mathrm{H}^{1}$ NMR $\left(\mathrm{DMSO}_{6}\right)$ $\mathrm{d}_{6}: 4.0$ $(\mathrm{s}, 1 \mathrm{H}, \mathrm{NH}), 7.5(\mathrm{~d}, 1 \mathrm{H}, \mathrm{CH} \mathrm{J}=3.9 \mathrm{~Hz}), 7.7$ (d,1H,CH J=3.6 $\mathrm{Hz}), 7.8$ (dd,2H,CH, J=2.6 Hz), 7.9 (d,1H,CH, J=2.6 $\mathrm{Hz}), 8.1(\mathrm{~d}, 1 \mathrm{H}, \mathrm{CH}, \mathrm{J}=2.4 \mathrm{~Hz}), 8.20(\mathrm{~d}, 1 \mathrm{H}, \mathrm{CH}, \mathrm{J}=6.3$ $\mathrm{Hz}), 8.3$ (dd, 2H,CH, J=1.8 Hz), 8.90 (s, 1H, CH); ${ }^{13} \mathrm{C}$ NMR (DMSO-d ${ }_{6}$ ) $\delta: 168.5,153.0,143.3,135.8,133.2$, $132.4,132.0,130.7,130.0,128.1,127.4,121.8,118.2$, 114.5; MS m/r: 295; calculated for $\mathrm{C}_{17} \mathrm{H}_{11} \mathrm{ClN}_{2} \mathrm{O}$ : C 69.28, H 3.76, N 9.50; found C 69.05, H 3.75, N 9.48. $R_{\mathrm{f}}=0.49$.

Cell culture. The human lung adenocarcinoma A549 cell line purchased from Health Protection Agency Culture Collections (ECACC, Salisburg, UK), was cultured in F12K medium (HyClone, UK) supplemented with $10 \%$ heat-inactivated fetal bovine serum (FBS), penicillin $(10 \mathrm{U} / \mathrm{ml})$ and streptomycin $(10 \mu \mathrm{g} / \mathrm{ml})$ in air with $5 \%$ $\mathrm{CO}_{2}$ at $37^{\circ} \mathrm{C}$.

Hypoxic cells were obtained by culturing in a hypoxic incubator in $1 \% \mathrm{O}_{2}$ and $5 \% \mathrm{CO}_{2}$ at $37^{\circ} \mathrm{C}$ for $24 \mathrm{~h}$ before treatment.

Cell viability/cytotoxicity assay. To determine anticancer activity of the analyzed compounds we evaluated cell viability using WST-1 assay (Millipore) according to manufactur's instruction. The assay is based on the conversion of the tetrazolium salt WST-1 to formazan by cellular mitochondrial dehydrogenases. Therefore, the amount of formazan dye formed directly correlates to the number of live cells in the culture.

A549 cells were seeded in 96-well plates at a density of 5000 cells/well and cultured in normoxic condition. To investigate the effect of compounds on hypoxic cancer cells, A549 cells were exposed to hypoxia $\left(1 \% \mathrm{O}_{2}\right)$ for $24 \mathrm{~h}$ before treatment. Stock solution of the tested compounds was prepared in DMSO and diluted in complete medium to give the final concentration in the range from 1 to $500 \mu \mathrm{M}$. Normoxic and hypoxic cells were treated with different concentrations of tested compounds or vehicle $(0.2 \%$ DMSO) for control cells. Cell viability was assessed after $48 \mathrm{~h}$ incubation with compounds in normoxic or hypoxic conditions. Briefly, WST-1 reagent was added to the cells and the absorbance was determined at $440 \mathrm{~nm}$ using a microplate reader (Synergy H1, Bio-Tek) after $3 \mathrm{~h}$ incubation at $37^{\circ} \mathrm{C}$. The percentage $(\%)$ of cell viability related to control cells was calculated by [A] test $/[\mathrm{A}]$ control $\times 100$. Where $[\mathrm{A}]$ test is the absorbance of the cells treated with compounds and [A] control is the absorbance of control cells. $\mathrm{IC}_{50}$ values (concentration of tested compounds required to reduce cell density to $50 \%$ ) were calculated by concentration-response curve fitting using a Microsoft Excelbased analytic method.

Apoptosis assay. Effect of compounds on cell apoptosis was determined using the Caspase Glo 3/7 assay [Promega] according to manufactur's instruction. The assay is based on measurement of caspase-3/7 activity via a proluminescent substrate containing the peptide DEVD (Z-DEVD-aminoluciferin). Following caspase cleavage, a substrate for luciferase is released resulting in the luciferase reaction and the production of luminescent signal.

A549 cells were seeded in white 96-well plates at a density of 5000 cells/well and cultured in normoxic or hypoxic conditions for $24 \mathrm{~h}$ before treatment with vehicle or selected compounds. Caspase $3 / 7$ activity in normoxic and hypoxic cells was measured after $4 \mathrm{~h}, 24 \mathrm{~h}$ and $48 \mathrm{~h}$ incubation with tested compounds. Luminescence values were measured by a microplate reader (Synergy H1, Bio-Tek) at gain 135.

Cell morphology. The effects of tested compounds at normoxia and hypoxia on cell morphology after $48 \mathrm{~h}$ treatment were evaluated by phase-contrast microscope (OptaTech).

Statistical analysis of the data. The results are expressed as mean \pm S.D. Statistical analysis was Student's $t$-test. $\mathrm{P}<0.05$ was considered significant.

\section{RESULTS AND DISCUSSION}

\section{Chemistry}

The method used to synthesize the benzimidazole derivatives and N-oxide benzimidazole derivatives is shown in Scheme 1. The cyclocondensation of diamine with aldehydes was conducted according to the described method (Jerchel et al., 1952; Pommier, 2006). We worked out conditions for obtaining new benzimidazole derivatives and $\mathrm{N}$-oxide benzimidazole derivatives, compounds which might possess anticancer properties and selective affinity to cells under hypoxic conditions.

Cyclization of the proper aryldiamine (1-2) with proper arylaldehyde (3-6) in anhydrous solvent at its boiling point gave benzimidazoles (7-12) (Fig. 1a) resulting in 55-70\% yields. N-oxide benzimidazole derivatives (13-18) (Fig. 1b) were obtained by direct reaction of $30 \%$ solution of hydrogen peroxide with benzimidazole derivatives, obtained in the first stage (7-12), in glacial acetic acid with 45-75\%. The synthetic process included reactions - Scheme 1. The structure of the new benzimidazole derivatives was established by X-ray crystal structure analysis (Błaszczak-Świątkiewicz et al., 2012).

\section{Biological activities}

Anticancer activity of newly synthesized benzimidazole derivatives (7-12) and N-oxide benzimidazole derivatives (13-18) was investigated in vitro on human lung adenocarcinoma A549 cells. The antiproliferative activity of compounds was examined by the WST-1 assay after a $48 \mathrm{~h}$ exposure. The results were expressed as fraction of viable cells. Cell apoptosis was determined by caspase $3 / 7$ activity assay. Changes in cell morphology induced 
<smiles>Nc1nc2cc(Br)ccc2[nH]1</smiles><smiles></smiles><smiles>C=C(N)c1cc(N2CC2)c(N)cc1N</smiles><smiles>Nc1n[n+]([O-])c2ccccc2[n+]1[O-]</smiles>

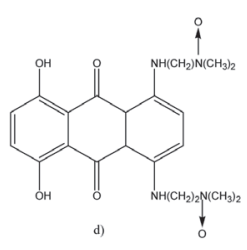

Figure 1. Structural formulas of analyzed compounds and known bioreductive prodrugs

(a) benzimidazole derivatives, (b) N-oxide benzimidazole derivatives (c) CB 1954, (d) AQ4N, (e) tirapazamine

by the compounds were visualized by phase-contrast microscopy. We also evaluated the anticancer effects of tested compounds in hypoxic cells. Tirapazamine was used as a reference drug.

\section{Effect of newly synthesized compounds on cancer cell viability in normoxia}

Concentration-response analysis was performed to determine compound concentrations required to inhibit the growth of cancer cells by $50 \%\left(\mathrm{IC}_{50}\right)$ after incubation for a $48 \mathrm{~h}$. Synthesized compounds were tested in a wide range of concentrations, from 1 to $500 \mu \mathrm{M}$. The fraction of live cells after treatment was evaluated by WST-1 assay.

Four out of 12 tested compounds showed $\mathrm{IC}_{50}$ values below $100 \mu \mathrm{M}$ in cells cultured in normoxic conditions (Table 1: compounds 7, 9, 13, 15). For comparison, in the same experimental conditions $162 \mu \mathrm{M}$ tirapazamine was required to inhibit the growth of A 549 cells by $50 \%$. Compound 7 and 13 were found to have a higher anticancer activity, with an $\mathrm{IC}_{50}$ value of $36.6 \pm 1.8 \mu \mathrm{M}$ and $24.4 \pm 2.6 \mu \mathrm{M}$, respectively. Culture of A459 cells in the presence of compound 7 at $30 \mu \mathrm{M}$ caused approximately $35 \%$ inhibition of cell growth compared to control cells. However, treatment of cells with compound 13 at the same concentration decreased cell viability by $87 \%$ (Fig. 2). These results demonstrated a much higher effectiveness of compound 13 compared to compound 7 at low concentration $(30 \mu \mathrm{M})$. A smaller effect on cell growth was observed after treatment with benzimidazole derivatives 9, $15\left(\mathrm{IC}_{50}\right.$ value $73.4 \pm 1.6 \mu \mathrm{M}$ and $72 \pm 2.7$ $\mu \mathrm{M}$, respectively). Other tested benzimidazole derivatives were less effective and showed much higher value of $\mathrm{IC}_{50}$ over the range $160-460 \mu \mathrm{M}$ (Table 1).

The results showed that benzimidazole derivatives which have a substituent of chlorophenyl (componds 7, 13) or piperonyl (compounds 9, 15) inhibited the growth of A549 cells more potently than analogous benzimidazole derivatives with nitrophenyl (compounds 8,14 ) or naphthyl (compounds 10, 16) groups.

These results are very similar to our earlier results of cytotoxic activity of new benzimidazole derivatives tested against of human malignant melanoma WM 115 cells (Oksuzoglu et al., 2008).

\section{Effect of new compounds on viability of hypoxic cells}

Tumor microenvironment characterized by hypoxia is the target of novel potential anticancer substances which have a bioreductive mechanism of action. For these reasons we also evaluated effects of our compounds on hypoxic cancer cells. A549 cells were exposed to hypoxia $\left(1 \% \mathrm{O}_{2}\right)$ for $24 \mathrm{~h}$ before treatment and were maintained in hypoxic condition during culture in the present of the compounds. As shown in Table 1, the most active agents among the benzimidazole series 7-18 in hypoxic conditions were compounds 7 and 13. In hypoxic conditions, the cell viability was significantly decreazed when cells were cultured in the presence of compounds 8 and 14. Both compounds at $56 \mu \mathrm{M}$ inhibited the growth of hypoxic tumor cells by approximately 50\% (comp. 7 - $\mathrm{IC}_{50}$ value $56.8 \pm 1.5 \mu \mathrm{M}$, comp. $13-\mathrm{IC}_{50}$ value $56.0 \pm 2.5$ $\mu \mathrm{M})$. Exposure of hypoxic cells to compound 8 and 14 at $97 \mu \mathrm{M}$ decreased cell survival by $50 \%$. Moreover, compound 14 was more effective in hypoxic cells compared to normoxic cells with $\mathrm{IC}_{50} 96.8 \pm 1.9$ $\mu \mathrm{M}$ and $460 \pm 1.5 \mu \mathrm{M}$, respectively. The same activity is characteristic for compound 8 . Beside the nitrobenzimidazole derivatives, chlorobenzimidazole derivatives showed promising activity as well. Compounds 11 and 17 demonstrated good antyproliferative properties, especially when we considered growth inhibition of compound 17 at hypoxia conditions (comp. $17-\mathrm{IC}_{50}$ value $190 \pm 1.1 \mu \mathrm{M}$ ). In contrast, compounds 9 and 16 showed no significant anticancer effect at any dose tested in hypoxic cells (Table 1, Fig. 2).

\section{Effect of compounds on cell apoptosis}

Based on their $\mathrm{IC}_{50}$ values, we selected compounds 7, 8, 13 and 14 for further biological evaluation. To evaluate if inhibition of cell growth in response to these compounds was due to induction of apoptosis, caspase $3 / 7$ activity was measured. Apoptosis assay was performed in normoxic and hypoxic A549 cells exposed to selected compounds at
Scheme 1. Synthesis of compounds 7-18. Reagents: $\mathbf{i}-$ anhydrous ethanol + nitrobenzene $48 \mathrm{~h}$, ii anhydrous acetic acid + hydrogen peroxide $24 \mathrm{~h}$.

nitrobenzene $48 \mathrm{~h}$, ii anhydrous acetic acid + hydrogen peroxide $24 \mathrm{~h}$.

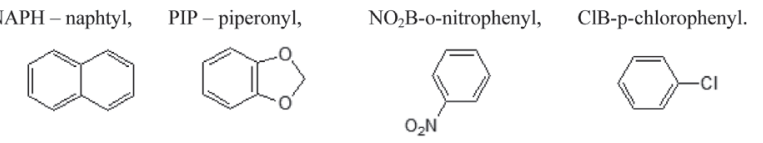


the $\mathrm{IC}_{50}$ concentration for different periods of time. Treatment of normoxic cells with compounds 7, 8, 13 and 14 did not increase the caspase $3 / 7$ activity over the control cell levels after a $24 \mathrm{~h}$ or $48 \mathrm{~h}$ exposure (Fig. 3). Similar results were obtained for hypoxic cells (Fig. 3). In contrast, treatment of normoxic and hypoxic cells with tirapazamine for $24 \mathrm{~h}$ increased caspase $3 / 7$ activity 4 -fold and 7 -fold compared to control cells for each condition, respectively (Fig. 3). These results suggest that these compounds at the tested concentrations inhibited A549 cell growth rather than by inducing apoptotic death. Moreover, our results demonstrated that culture of the cells in hypoxia decreased caspase $3 / 7$ activity approximately 2-fold (Fig. 3A) and 7-fold (Fig. 3B) compared to control normoxic cells. These results showed that generally hypoxia contributes to increased cancer cell survival by attenuation of cell apoptosis, not necrosis. Screening test of caspase-dependent apoptosis of tested compounds for a $48 \mathrm{~h}$ hypoxic and normoxic
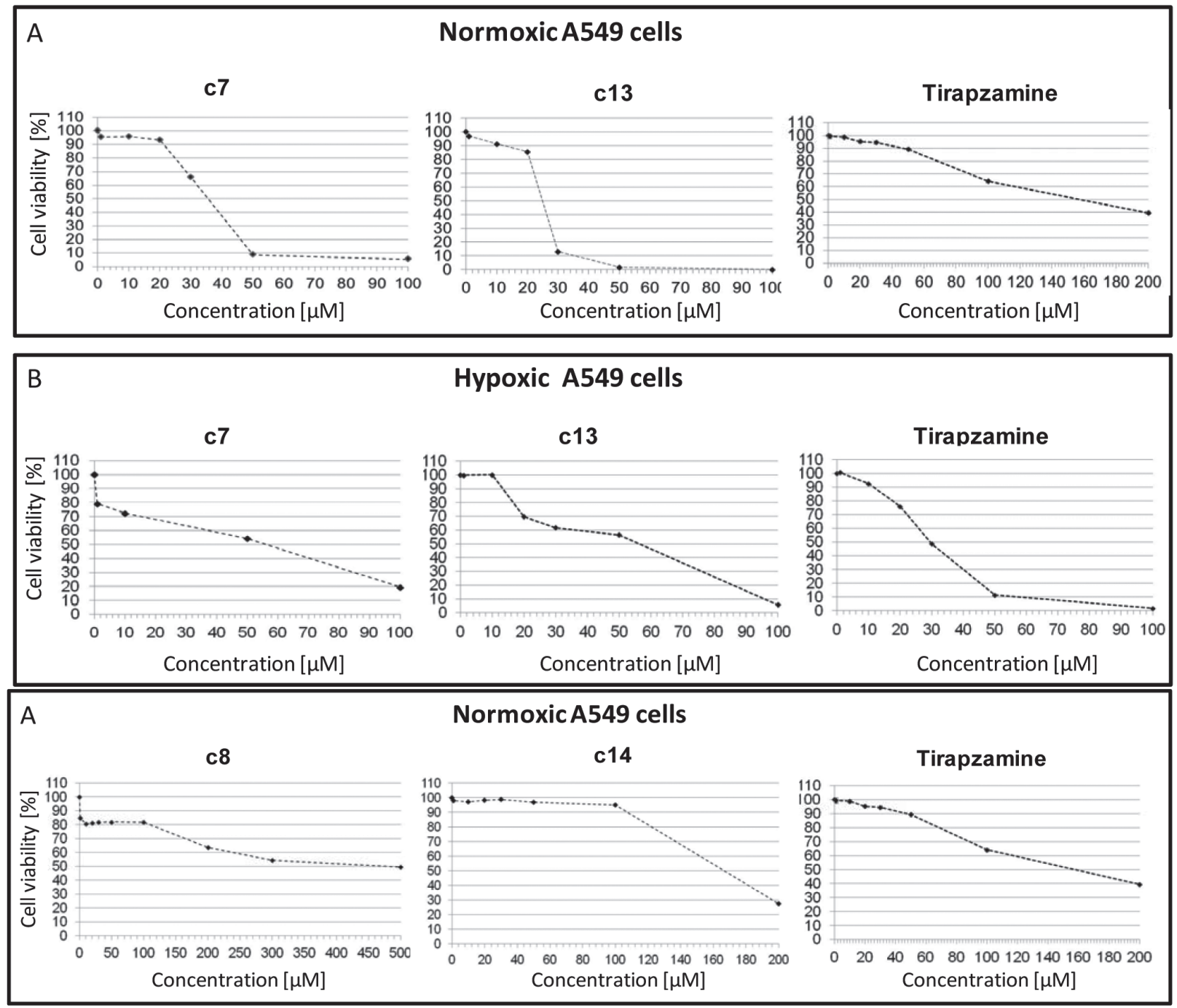

B

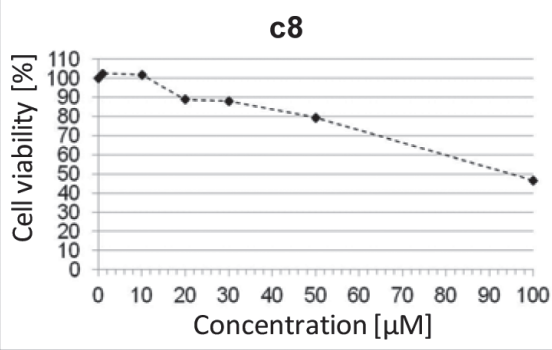

Hypoxic A549 cells
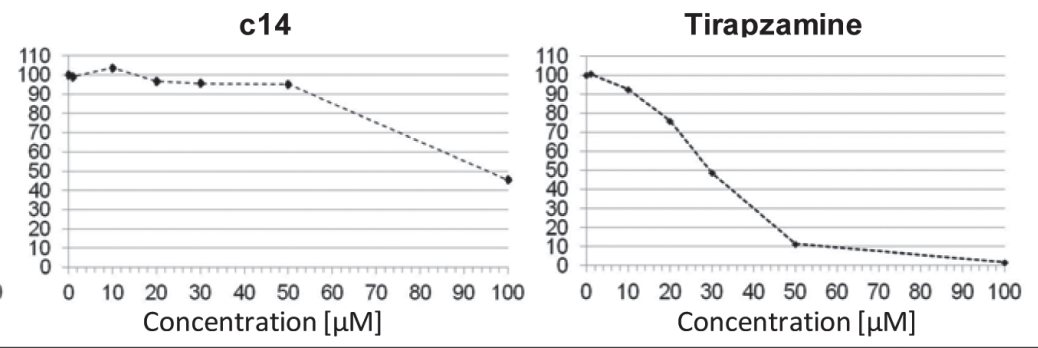

Figure 2. Effect of compounds 7, 813 and 14 on cancer cell viability.

Normoxic and hypoxic A549 cell were cultured in the present of different compounds at indicated concentrations. Cell viability was determined by WST-1 assay after $48 \mathrm{~h}$ treatment. Data are expressed as a mean \pm S.D., $\mathrm{n}=3$. 

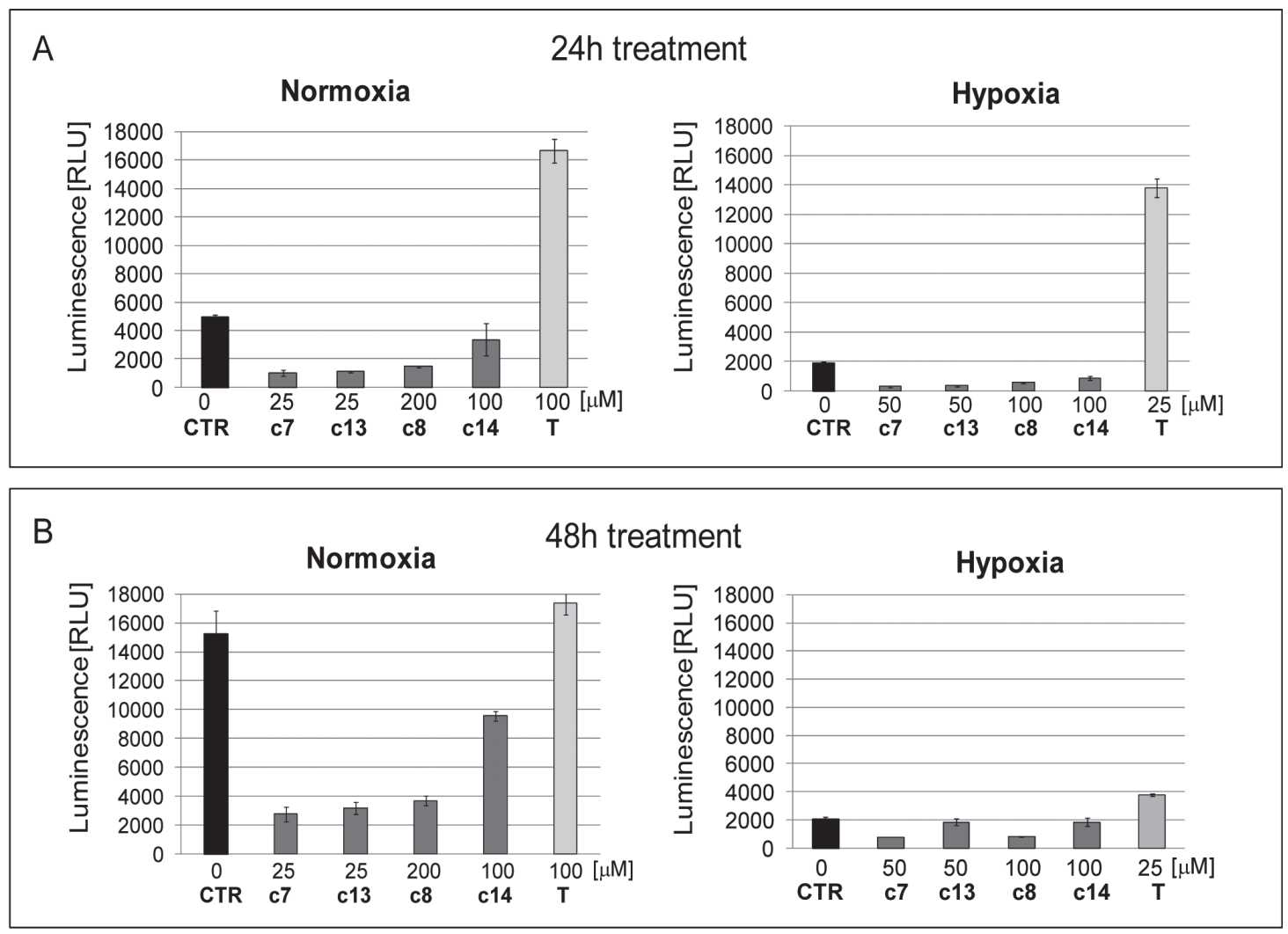

Figure 3 Effects of compounds 7, 8, 13, 14 and tirapazamine on cell apoptosis in normoxic and hypoxic conditions.

Normoxic and hypoxic A549 cells were cultured in the presence or absence (CTR, control) of selected benzimidazole derivtives and tirapazamine $(\mathrm{T})$ as a reference compound at indicated concentrations. Cell apoptosis was determined by caspase $3 / 7$ activity assay after $24 \mathrm{~h}$ and $48 \mathrm{~h}$ treatment. Caspase activity was measured as luminescence intensity [RLU] and expressed as mean \pm S.D., $\mathrm{n}=3$.

Table 1. In vitro growth inhibition of selected tumor cell lines by new benzimidazole derivatives.

\begin{tabular}{llll}
\hline & $\mathrm{IC}_{50}[\mu \mathrm{M}] \mathrm{A} 549$ & & Differential \\
\hline \multirow{2}{*}{ Compound } & Normoxia & Hypoxia & $\begin{array}{l}\text { cytotoxicity } \\
\mathrm{O} / \mathrm{H}\end{array}$ \\
\hline 7 & $36.6 \pm 1.8$ & $56.8 \pm 1.5$ & 0.64 \\
\hline 8 & $169.2 \pm 1.5$ & $97.4 \pm 1.4$ & 1.74 \\
\hline 9 & $73.4 \pm 1.6$ & No & No \\
\hline 10 & $379.5 \pm 1.6$ & $254 \pm 0,4$ & 1.49 \\
\hline 11 & $181.7 \pm 1.9$ & $165.0 \pm 1.6$ & 1.10 \\
\hline 12 & $293.2 \pm 1.2$ & $270.0 \pm 0.8$ & 1.08 \\
\hline 13 & $24.4 \pm 2.6$ & $56.0 \pm 2.5$ & 0.43 \\
\hline 14 & $460 \pm 1.5$ & $96.8 \pm 1.9$ & 4.75 \\
\hline 15 & $72.0 \pm 1.7$ & $350.0 \pm 1.1$ & 0.2 \\
\hline 16 & $279.0 \pm 2.2$ & No & No \\
\hline 17 & $164.4 \pm 2.1$ & $190 \pm 1.1$ & 0.86 \\
\hline 18 & $300.9 \pm 1.8$ & $398 \pm 0.2$ & 0.75 \\
\hline Tirapazamine & $162.2 \pm 0.6$ & $29.0 \pm 1.5$ & 5.59 \\
\hline
\end{tabular}

WST-1 assay was used to determine inhibition of cell growth after $48 \mathrm{~h}$ incubation with tested compounds. $\mathrm{IC}_{50}$ values (concentration of tested compounds causing $50 \%$ inhibition of cell growth compared to control cells) were calculated and expressed as mean \pm S.D., $n=3$. No - indicates no effect or less than $50 \%$ inhibition of cell growth of tested compound. exposure showed promoting apoptotic cell death in relation to necrotic death.

\section{CONCLUSION}

Compounds 7 and 13 were the most effective in inhibiting growth of normoxic as well as hypoxic A549 cells. Compounds 8 and 14 were more potent to specifically inhibit cell viability of hypoxic cancer cells while they were less effective in normoxic cells. Moreover, hypoxic/aerobic cytotoxicity coefficient of compound $\mathbf{8}$ was 4.75 while for tirapazamine it was 5.59 . This parameter locates compound 8 between mitomycine C (cytotoxic coefficient from 1-5) and 2-nitroimidazole (misonidazole) with toxicity coefficient 5-15. As we showed at control samples at Fig. 3, normoxia didn't limit proliferation and opposite to hypoxia, the density of cells at normoxia was enhanced. This was direct cause of increasing of tumor cells death at control sample at normoxia. Because of this reason we found that benzimidazoles at hypoxia conditions promote cell death more by apoptosis than necrosis. In our opinion apoptosis depends on increasing of inhibition of tumor cells' proliferation by benzimidazoles as a bioreductive agents.

\section{Acknowledgments}

The study was supported by the Medical University of Lodz, Poland (503-3015-1, Grant No. 507-13-052). 


\section{REFERENCES}

Albertella MR, Loadman PM, Jones PH (2008) Hypoxia-selective targeting by the bioreductive prodrug $\mathrm{AQ} 4 \mathrm{~N}$ in patients with solid tumors: results of a phase I study. Clin Cancer Res 14: 1096-1104.

Alpan AS, Gunes HS, Topcu Z (2007) 1H-Benzimidazole derivatives as mammalian DNA topoisomerase I inhibitors, Acta Biochim Pol 54: $561-565$.

Alpan AS, Zupko SZ, Coban G, Rethy B, Gunes HS, Topcu Z (2009) Biological activity of bis-benzimidazole derivatives on DNA topoisomerase I and HeLa, MCF7 and A431 cells. I Ensyme Inbibit Medi Chem 24: 844-849.

Alper S, Arpaci OT, Aki ES, Yalcin I (2003) Some new bi- and terbenzimidazole derivatives as topoisomerase Inhibitors. II Farmaco 58: 497-507.

Błaszczak-Świątkiewicz K, Mikiciuk-Olasik E (2008) Role of hipoxia in advances in new anticancer diagnostics and therapy. Wiadomości Chemiczne 62: 11-12, 1065-1089 (in Polish).

Błaszczak-Świątkiewicz K, Mirowski M, Kaplińska K, Kruszyński R, Trzęsowska-Kruszyńska A, Mikiciuk-Olasik E (2012) New benzimidazole derivatives with potential cytotoxic activity - study of their stability by RP-HPLC. Acta Biochim Pol 59: 279-288.

Coban G, Zencir S, Zupko I, Rethy B, Gunes HS, Topcu Z (2009) Synthesis and biological activity evaluation of $1 H$-benzimidazoles via mammalian DNA topoisomerase I and cytostaticity assays. Eur J Med Chem 44: 2280-2285.

Forsythe JA, Jiong BH, Iyar NV (1996) Activation of endothelial growth factor gene transcription by hypoxia-inducible factor 1 . Mol Cell Biology 16: 4604-4613.

Jerchel D, Fischer H, Kracht M (1952) Zur darstellung der benzimidazole. Justus Liebigs Annalen der Chemie 575: 162.

Kim JW, Tchernyshyov I, Semenza GL (2006) HIF-1-mediated expression of pyruvate dehydrogenase kinase: a metabolic switch required for cellular adaptoation to hypoxia. Cell Metabolism 3: 177-185.

Kurtzberg LS, Roth S, Krumbholz R, et al. (2001) Genz-644282, A Novel Non-Camptothecin Topoisomerase I Inhibitor for Cancer Treatment. Clin Cancer Res 17: 2777-2787.
Lazowski J (1999) Clinical pharmacology of irinotecan. Farmacja Polska 55: 28-34 (in Polish).

McKeown SR, Cowen RL, Williams KJ (2007) Bioreductive drugs: from concept to clinic. Clin Oncol 19: 427-442.

Meng L, Liao Z, Pommier Y (2003) Non-camptothecin DNA topoisomerase I inhibitors in cancer therapy. Curr Topics Med Chem 3: 305-320.

Mikiciuk-Olasik E, Błaszczak-Świątkiewicz K, Żurek E, Krajewska U, Różalski M, Kruszyński R, Bartczak TJ (2004) New derivatives of quinazoline and 1,2-dihydroquinazoline $\mathrm{N}^{3}$-oxide with expected antitumour acivity. Archiv der Pharmazie 337: 239-246.

Oksuzoglu E, Tekiner-Gulbas B, Amper S (2008) Some benzoxazoles and benzimidazoles as DNA topoisomerase I and II inhibitors. J Enzyme Inhibit Med Chem 23: 37-42.

Omyła-Staszewska J, Deptała A (2003) Topoizomerase I inhibitors a uniqe class of anticancer drugs. Wspótczesna Onkolgia 7: 45-53 (in Polish).

Panieres GC, Bonifas IA, Guadalupe JC, Lopez JE, Guadalupe G, Alvarez CT (2000) Synthesis of benzimidazoles in dry medium. Synthetic Commun 30: 2195.

Preston PN (1974) Synthesis, reactions and spectroscopic properties of benzimidazoles. Chem Rev 74: 279-314.

Pommier Y (1999) Topoisomerase I inhibitors: camptothecins and beyond. Nat Rev Cancer 6: 789-802.

Semenza GL (1999) Regulation of mammalian O2 homeostasis by hypoxia-inducible factor 1. Ann Rev Cell Develop Biol 15: 551-578.

Singh M, Tandon V (2011) Synthesis and biological activity of novel inhibitors of topoisomerase I: 2-Aryl-substituted 2-bis-1H-benzimidazoles. Eur I Med Chem 46: 659-669.

Vaupel P (2004) The role of hypoxia-induced factors in tumor progression. The Oncology 9: 10-17.

Wu N, Wu X, Agama K, Novel A (2010) DNA Topoisomerase I inhibitor with different mechanism from camptothecin induces $\mathrm{G} 2 / \mathrm{M}$ phase cell cycle arrest to K562 cells. Biochemistry 49: 10131-10136. 